\title{
Shifting the Focus from an International Towards a more Regional Cultural Heritage Protection in the Middle East and North Africa
}

\author{
By Lando Kirchmair*
}

\begin{abstract}
This article seeks to contribute to shifting the focus from an international, towards a regional cultural heritage protection in the Middle East and North Africa (MENA). While especially the destruction of Palmyra has drawn much of worldwide attention, this has wrongly led to an exaggerated impression of a region in need of international interventionism. An example of such an excessive internationalism is the call for international action triggered by the announced status change of the Hagia Sophia. In contrast to a too dominant international focus, this contribution aims to put a spotlight on the regional framework for the protection of cultural heritage in the MENA. By sketching regional cultural heritage protection, this article wants to contribute to laying the ground for future research on the topic, delving more into the normative potential as well as the empirical realities of the day-to-day protection of cultural heritage in the MENA.
\end{abstract}

$* * *$

\section{A. Introduction}

Cultural heritage in the Middle East and North Africa (MENA) has caused worldwide upheaval lately. While in July 2020, Turkey aroused international reactions by announcing to change the status of the Hagia Sophia into a mosque again, in 2014/2015, the destruction of cultural heritage in Syria (Palmyra) and Iraq (Nimrud and Nineveh) by the so-called "Islamic State" (ISIS), as well as in 2012, the destruction of cultural heritage sites in Timbuktu by Ansar Dine and al-Qaeda in the Islamic Maghreb, terrified the international community. Also the looting of artifacts in Syria since 2011 has been both, a solid financial income for ISIS and a source of concern for those holding high a common cultural heritage. Even though the destruction of the Buddhas of Bamiyan in the Hazarajat region of central Afghanistan by the Taliban dates back to March 2001 and the region usually is not directly associated with the MENA, this devastating event remains in the memory of the interna-

* Prof. Dr. iur. Dr. habil. Lando Kirchmair, is Deputy Professor for National and International Public Law with a Focus on the Protection of Cultural Heritage, Department of Social Sciences and Public Affairs, Bundeswehr University Munich, and Co-PI, European Constitutional Court Network project, Faculty of Law, University of Salzburg. Contact: lando.kirchmair@unibw.de. I am grateful to Jan Busse, Cornelia Schäffer, Donald Riznik and two anonymous reviewers for very helpful comments, and to AGYA for supporting the open access publication. 
tional community, too, and is - at least in a broader perspective - in a way a forerunner of cultural heritage destruction by ISIS.

These events, however, are of a largely different nature. Different actors, different motivations, different contexts should arguably be kept apart. This article holds that especially iconoclasm and illegal trafficking of cultural property by terrorist organizations has contributed to an image of a region, which is in need of international support if not even an intervention, ${ }^{1}$ in order to uphold cultural heritage protection. This, however, is problematic. While some events might indeed call for international solutions, the focus of cultural heritage protection in the MENA should rather be more regional than international. A brief retelling of the mentioned events will showcase that we should aim for a clear differentiation between various dangers for cultural heritage protection and the most probable tools of protection (B.). This enables us to making the case (C.) and cautiously providing further ground (D.) for a stronger focus on the regional cultural heritage protection in the MENA. Finally, this article ends with a conclusion and an outlook (E.).

\section{B. Despite the (Staged) Iconoclasm in and nearby the MENA, the Image of the MENA in Desperate Need of International Support or even Intervention for Cultural Heritage Protection Is Doubtful}

Iconoclasm, broadly understood as "the destruction or alteration of images or objects imbued with some kind of symbolic value"2, has a long history reaching back to Byzantium, and "Emperor Leo III's introduction of imperial iconoclasm in 726 ". ${ }^{3}$ Yet, the complete destruction of the Bamiyan Buddhas in Afghanistan in 2001 by the Taliban - which had been compared to the destruction of the Artemis Temple in $356 \mathrm{BC}^{4}-$ marks a distinct element of iconoclasm in the early $21^{\text {st }}$ century. In a globalized and at least medially well connected world a new stage has been introduced to the phenomenon. ${ }^{5}$ In fact, this destruction is con-

1 Think of the initiative blue helmets for culture ("unite4Heritage"), for instance, UN SC Res 2347 (2017), available at https://www.un.org/en/ga/search/view_doc.asp?symbol=S/RES/2347(2017) (last accessed on 10 September 2020).

2 See, Kristine Kolrud / Marina Prusac, Introduction - Whose Iconoclasm?, in: Kristine Kolrud / Marina Prusac (eds.), Iconoclasm from Antiquity to Modernity, New York 2014, p. 1, 1.

3 Kolrud / Prusac, note 2, p. 4. C.f., however, also Leslie Brubaker, Iventing Byzantine Iconoclasm, London 2012, stating that origins of iconoclasm are more complex than usually claimed. For instance, to her (p. 125), "more modern iconoclasms - from that practiced during the Reformation and the French Revolution to that advocated by the modern Taliban - have equally little in common with Byzantine iconomachy, because they all involve the active destruction of cult objects, which the Byzantines very seldom engaged in."

4 See Pierre Centlivres, The Controversy over the Buddhas of Bamiyan, South Asia Multidisciplinary Academic Journal 2 (2008), p. 1.

5 See Kolrud / Prusac, note 2, p. 8, pointing to "the audience that makes the accusation real" (quoting Mia Mochizuki) C.f. Brooke Barnett / Amy Reynolds, Terrorism and the Press. An Uneasy Relationship, New York 2009, p. 1 claiming that "[b]reaking news is the new vehicle to transport the terrorist message." See also Kristine Kolrud, The Waldensians and the Piedmontese Easter of 1655, in: 
sidered in the same framework of cultural iconoclasm with the subsequent attack on the World Trade Center on 11 September $2001 .^{6}$ The successful intention was to create a worldwide uproar. And even though the region affected was not what is typically referred to as the MENA, the Buddha statues carved out of rock in the $6^{\text {th }}$ to $7^{\text {th }}$ century BC in the Bamiyan valley were used as a showcase and thereby constituted the beginning of a new media-centred act of terrorism against cultural heritage, which had a lasting impact on the MENA. ${ }^{7}$ Paradoxically, this surgically orchestrated savage act $^{8}$ displays the importance of cultural heritage for a society - be it international or regional - better than any other act. ${ }^{9}$ In the violent act of demolition, the prominence and weight of the object becomes apparent. ${ }^{10}$ This inspired in a way the crimes against cultural heritage protection in the MENA a decade later.

Palmyra, also known as "Tadmur", has a long history dating back to the early second millennium BC. ${ }^{11}$ Major international attention, however, was directed towards this world heritage site because of its destruction by ISIS in 2014 and 2015. While the institutionalized looting of art has constituted a significant source of income for the terrorist group, which affected for instance the $9^{\text {th }}$ century BC Grand Palace of the Assyrian King Ashur-

Kristine Kolrud / Marina Prusac (eds.), Iconoclasm from Antiquity to Modernity, New York 2014, p. 139 giving the example of "printed propaganda" after the invention of the printing press.

6 Lynn Meskell, Negative heritage and past mastering in archaeology, Anthropological Quarterly 75 (3) (2002), p. 557, 561.

7 See, e.g., Michael Falser, The Bamiyan Buddhas, performative iconoclasm and the "image" of heritage, in: Simone Giometti / Andrzej Tomaszewski (eds.), The Image of Heritage. Changing Perception, Permanent Responsibilities, Florence 2011, p. 157.

8 See Henry Chapman, Iconoclasm and later prehistory, London 2018, p. 19 "After about twenty days of attacks to the statues using a range of methods from hand tools to grenades, anti-aircraft missiles, bombs and tanks, the Taliban turned to specialists to blow up the two images professionally; an act reminiscent of the commissioning of Pierre-François Palloy to destroy statues and other symbols during the French Revolution."

9 This stands against the statement by Qudratullah Jamal on $3^{\text {rd }}$ March 2001 "It is not a big issue. The statues are objects only made of mud or stone", quoted after Derek Gillman, The Idea of Cultural Heritage, rev. ed. New York 2010, p. 9; c.f. ibid p. 12 stating that "[a]1l over Afghanistan, and within the Kabul Museum itself, Taliban authorities were endorsing a systematic iconoclasm to remove as much pre-Islamic sculpture as possible."

10 C.f. on this point, Michael Taussig, Iconoclasm Dictionary, in: Rachel F. Stepleton / Antonio Viselli (eds.), Iconoclasm. The Breaking and Making of Images, Montreal 2019, p. 21 embracing a Foucauldian conception of icons asking whether it might be possible that "the power of icons, like the power of iconoclasm, depends on [the] presence made intimate". Additionally asking "what could be more intimate than destruction". Continuing that "[t]his would explain why icons suddenly burst into consciousness and seem to come alive only with their defacement. You smash them and - lo and behold! - they have become icons".

11 For - partially contrasting - overviews, on Palmyra generally, see, e.g, Paul Veyne, L'irremplaçable trésor, Paris 2015; and Annie Sartre / Maurice Sartre, Palmyre: Vérités et légendes, Paris 2016; as well as with a focus on Palmyrene art Andreas Kropp / Rubina Raja (eds.), The World of Palmyra, Copenhagen 2016. 
nasirpal II at Kalhu, whose artefacts "were broken up, sold piecemeal and recovered in various European cities [, in what] is but one example of the large-scale sell off conducted by [ISIS]". ${ }^{12}$ This situation was aggravated by the public beheading of the Director of Antiquities in Palmyra, Khaled al-As'ad by ISIS on 18 August 2015, which was another particularly dark moment for international cultural heritage protection in the young $21^{\text {st }}$ century, and on 23 August 2015, when ISIS destroyed the Temple of Bel, to mention just two more tragic events. On 5 October 2015, ISIS obliterated also the Roman monumental Arch of Triumph in Palmyra and the list could be continued and filled with far too many objects of importance in the realm of cultural heritage protection. ${ }^{13}$ Again, this was a very devastating moment for the international heritage community in particular, and the international community at large as cultural property has been instrumentalized as "a weapon of war". ${ }^{14}$

Given such a blatant disregard for cultural heritage protection it was somewhat relieving for the compassionate international community, when the International Criminal Court (ICC) fostered the international rule of law. In 2012, Ahmad Al Faqi Al Mahdi, intentionally directed attacks against cultural objects in Timbuktu, Mali. In what is now internationally known as the "Al-Mahdi Case", the ICC convicted - for the first time in the history of the ICC - in 2016 an individual of having committed the war crime of attacking cultural property according to Article 8 (2) (e) (iv) ICC-Rome Statute. ${ }^{15}$ Al Mahdi was sentenced to nine years by the ICC Trial Chamber for attacking religious and historical buildings in the Malian city of Timbuktu. He served - from April to September 2012 - as the head of the Hesbah, and overlooked and participated at the request of Ansar Dine and Al Qaeda in the Islamic Maghrib (AQIM), two armed groups which took control of Timbuktu in April 2012 imposing religious and political rule over the territory until January 2013, in the attack on Timbuktu's mosques and mausoleums. ${ }^{16}$ Although this case is crucial for international cultural heritage law, ${ }^{17}$ it is important not to overlook that "in determining whether future cases based on the war crime of destruction of cultural property should be brought before the

12 See, eg, Kirsten Schmalenbach, Ideological Warfare against Cultural Property: UN Strategies and Dilemmas, Max Planck Yearbook of United Nations Law 19 (1) (2016), p. 1, 5.

13 For an overview with further references, see Helga Turku, The Destruction of Cultural Property as a Weapon of War. ISIS in Syria and Iraq, Cham 2018, p. 2.

14 Turku, note 13.

15 ICC, The Prosecutor v. Ahmad Al Faqi Al Mahdi, 27 September 2017, No ICC-01/12-01/15. For an analysis, see, e.g, Uzma S. Bishop-Burney, Prosecutor v. Ahmad Al Faqi Al Mahdi, American Journal of International Law 111 (1) (2017), p. 126; c.f. also Ana Filipa Vrdoljak, Prosecutor v. Ahmad Al Faqi Al Mahdi: Judgment and Sentence \& Reparations Order (Int'l Crim. Ct.), International Legal Materials 57 (1) (2018), p. 17.

16 See for details Bishop-Burney, note 15.

17 This was of importance as the individual criminal responsibility of cultural heritage destruction was permanently institutionalized by the ICC. Yet, while the Al Mahdi case was the first conviction by the ICC, the Statute of the International Criminal Tribunal for the Former Yugoslavia (ICTY) provided in Art 3 (d) for individual criminal responsibility for the violation of cultural property. Miodrag Jokić was the first individual who had to serve a seven years sentence in 2004 
ICC, the Prosecutor and Chambers should depart from the prevailing universalist reasoning and instead utilize a relativist approach to identifying the gravity of the destruction in question."18 In other words, when holding individuals internationally accountable for committing war crimes, it is important not to lose sight of the regional impact of such crimes. Regarding the case of $\mathrm{Al}$ Mahdi, however, it is important to bear in mind that it was Mali itself which referred the situation in July 2012 to the ICC. Given this fact, the regional focus arguably was taken into account.

These events have caused a lot of international attention and, in a way, they conveyed an image of the MENA, implying difficulties to protect its cultural heritage - to put it mildly. The rising skepticism of the international community is all the more stirred by a global heritage discourse which shifts more and more towards an understanding of a common heritage of mankind, which easily results then in a rising call for international intervention for instance represented by the call for Blue Helmets for Culture. ${ }^{19}$ Despite - or rather because - of these traumatic events and the image portrayed, this contribution seeks to move the spotlight to a different, forward-looking perspective of cultural heritage protection in the MENA. While the discussion on virtual heritage protection and reconstruction largely speaks to the technical side of such a prospect (again headed by international and mostly

for the deliberate destruction of cultural property in the old town of Dubrovnik (ICTY Prosecutor v. Jokić, Trial judgment, Case No IT-01-42/1-S, 18 March 2004). The Trial Chamber explicitly stated that "this crime represents a violation of values especially protected by the international community" (ICTY Prosecutor v. Jokić [2004] at para 46). Furthermore, the jurisdiction of the International Military Tribunal (IMT) at Nuremberg included violations of the laws and customs of war. And Art. 6 (b) of the Charter of the International Military Tribunal, Nuremberg annexed to the Agreement by United Kingdom, United States, France and USSR for the Prosecution and Punishment of the Major War Criminals of the European Axis, 8 August 1945, 82 UNTS 279, listed as a war crime inter alia also the "plunder of public or private property, wanton destruction of cities, towns or villages, or devastation not justified by military necessity." Alfred Rosenberg was sentenced to death amongst other things for being "responsible for a system of organized plunder", see International Military Tribunal, Nuremberg, Judgment, American Journal of International Law 41 (1947), p. 172, 237. C.f. Ana Filipa Vrdoljak, The Criminalisation of the Intentional Destruction of Cultural Heritage, in: Tiffany Bergin / Emanuela Orlando (eds.), Forging a Socio-Legal Approach to Environmental Harms, London 2017, p. 237, 240 et seq; as well as Micaela Frulli, International Criminal Law and the Protection of Cultural Heritage, in: Ana Filipa Vrdoljak / Francesco Francioni (eds.), The Oxford Handbook of International Cultural Heritage Law, Oxford 2020, p. 100.

18 Paige Casaly, Al Mahdi before the ICC: Cultural Property and World Heritage in International Criminal Law, Journal of International Criminal Justice 14 (5) (2016), p. 1199, 1200.

19 See Sabine von Schorlemer, Der Schutz von Kulturerbestätten als Aufgabe der UN-Sicherheitspolitik, Vereinte Nationen 1 (2016), p. 1 discussing - amongst other things - also the initiative Blue Helmets for Culture as a means to make the international legal order more robust to fight intentional destruction of cultural heritage. C.f. on this Gabriele D'amico Soggetti, Blue Helmets for Culture: Involving Communities in the Protection of Their Heritage, in: Evelyne Lagrange / Stefan Oeter / Robert Uerpmann-Wittzack (eds.), Cultural Heritage and International Law, Wiesbaden 2018, p. 163 rightly arguing that the "initiative's ultimate success will depend on reaching out and involving the local communities". 
Western scholars and institutions), ${ }^{20}$ this contribution wants to address the normative stance. It is argued, that the normative centre of cultural heritage protection should ideally be regional and only subsequently international. ${ }^{21}$

A case at hand for an arguably ill-suited international intervention in regional cultural heritage issues is the recently announced status change of the Hagia Sophia in Istanbul. This article argues that the events just described have led to an image of a region which is not able to protect its cultural heritage. Therefore, too easily the claim for an international intervention is made, even though different events call for different solutions. The announcement by Recep Tayyip Erdoğan to change the status of the Hagia Sophia and to turn it into a Mosque on Friday, 10 July 2020, has provoked a worldwide outcry. ${ }^{22}$ With a ruling of 2 July 2020, published also on Friday, 10 July 2020, ${ }^{23}$ the Council of State, Turkey's highest administrative court, invalidated the 1934 transformation of the Hagia Sophia from a Mosque into a museum. On the day the court ruling was released, the Turkish President signed a decree, ${ }^{24}$ opening the UNESCO world heritage site - once again - to Muslim worshipers. Consequently, the Hagia Sophia ceases to be a public museum, becomes a Mosque again. The inaugurating Friday prayers took place on 24 July 2020, coinciding with the 97th anniversary of the conclusion of the Treaty of Lausanne in 1923. This is yet again a historic change in the long history of the Hagia Sophia, which was built in 537 AD on the orders of emperor Justinian I, constituting once the world's largest church. Following the

20 For an overview of the status of the niche left in the rock after the demolition of the Bamiyan Buddhas, see for instance, Institut für Bodenmechanik und Grundbau, Untersuchung von Zustand und Stabilität der Felsnischen der Buddha-Statuen von Bamiyan, available at https://web.archive.org/w eb/20160304032715/http://www.unibw.de/bauv5/forschung/abgeschlossene_forschungsvorhaben/ buddha (last accessed on 10 September 2020). See, e.g., also Wissam Wahbeha / Stephan Nebikera / Gabriele Fangi, Combining Public Domain and Professional Panoramic Imagery for the Accurate and Dense 3D Reconstruction of the Destroyed Bel Temple in Palmyra, ISPRS Annals of the Photogrammetry, Remote Sensing and Spatial Information Sciences 3 (5) (2016), p. 81; or Ahmet Denker, Rebuilding Palmyra virtually: recreation of its former glory in digital space, Virtual Archaeology Review 8 (17) (2017), p. 20. For a discussion of how "destruction and reconstruction of Syria's heritage have been deployed to serve political agendas", see Nour A. Munawar, Reconstructing Cultural Heritage in Conflict Zones: Should Palmyra be Rebuilt?, EX NOVO Journal of Archaeology 2 (2017), p. 33. For a pointed argument that the West should not engage in a reconstruction, see Interview of Andrea Zederbauer with Andreas Schmidt-Colinet, 'We should do nothing!' On the history, destruction and rebuilding of Palmyra, Eurozine (22 December 2017), available at https://www.eurozine.com/we-should-do-nothing-on-the-history-destruction-and-rebuilding -of-palmyra/ (last accessed on 10 September 2020).

21 See on this below, C.

22 For a brief analysis, see Lando Kirchmair, Turning Hagia Sophia into a mosque (again). Has international law anything to say about that?, Völkerrechtsblog, 21 July 2020, available at https://voelk errechtsblog.org/turning-hagia-sophia-into-a-mosque-again/ (last accessed on 10 September 2020).

23 No 2020/2595, https://danistay.gov.tr/upload/guncelkarar/10_07_2020_060019.pdf (last accessed on 10 September 2020).

24 Decree no 2729, https://www.resmigazete.gov.tr/eskiler/2020/07/20200710M1-1.pdf (last accessed on 10 September 2020). 
conquest of Constantinople by Sultan Mehmed II in 1453, it was immediately converted into a Mosque. The founder of modern Turkey, Mustafa Kemal Atatürk, transformed the Hagia Sophia some 500 years later, on 24 November 1934, into a museum. As a museum, it lasted from 1 February 1935 until 10 July 2020. This status change met worldwide opposition. For instance, Pope Francis disclosed that he is "very saddened" by this decision, ${ }^{25}$ the Greek Prime Minister Kyriakos Mitsotakis "condemned" it, ${ }^{26}$ and also UNESCO expressed its "deep regret", calling upon the Turkish authorities "to initiate dialogue without delay" and announcing that "the state of conservation [...] will be examined by the World Heritage Committee at its next session" 27 . Sad news coming from the Middle East, at least from the perspective of international heritage protection. While the status change - and a mere reduction of opening hours due to the restrictions when prayers take place - does not directly violate international law, it is primarily the symbolism conveyed by this decision, which comes in a nationalist and sovereignty focused language - in contrast to tolerance and international cooperation. ${ }^{28}$

Nevertheless, it is precisely this last example which is meant to show, that it is very important to differentiate. While some events such as large scale mutual destruction of cultural heritage might sometimes overburden a more regionally oriented cultural heritage protection, a more cautious and also reluctant international stance on cultural heritage protection might be more favorable in less severe cases. While international individual criminal responsibility for cultural heritage destruction can provide for support for the (international) rule of law, it surely strengthens the legitimacy of such convictions that the situation is referred to the ICC by the State concerned from a regional perspective. ${ }^{29}$

25 Vatican News, Pope Francis: 'I think of Hagia Sophia, and I am very saddened', 12 July 2020, https://www.vaticannews.va/en/pope/news/2020-07/angelus-pope-remembers-seafarers.html (last accessed on 10 September 2020).

26 Reuters, Greece condemns Turkey's decision to convert Hagia Sophia into mosque, 10 July 2020, https://www.reuters.com/article/us-turkey-museum-verdict-greece/greece-condemns-turkeys-decis ion-to-convert-hagia-sophia-into-mosque-idUSKBN24B2UF (last accessed on 10 September 2020).

27 See UNESCO statement on Hagia Sophia, 10 July 2020, https://en.unesco.org/news/unesco-statem ent-hagia-sophia-istanbul (last accessed on 10 September 2020).

28 See Kirchmair, note 22.

29 Note that this is not to say that in other situations the ICC might lack legitimacy. Yet, it might be important to bear in mind that due to its strong relation to identity questions a regional focus is particularly important for cultural heritage protection, when situations are referred to the ICC by the UN Security Council according to Article 13 (b) of the Rome Statute. 


\section{Making the Case for a Regional and not Primarily Eurocentric, Western or International Cultural Heritage Protection - Or in Whose Interest Is the Protection of Cultural Heritage in the MENA?}

"Calling on the 'heritage of all mankind' is certainly useful if we want to stop destruction, looting, decay or benign neglect, and where we want to signal to the agents of such change that they should think about values other than their own"30, says the renowned cultural heritage expert Derek Gillman. He is, however, aware that despite such claims "to preserve important cultural things on behalf of all mankind may be noble and worthy of our support in principle", other competing social facts might be in conflict with such intentions. ${ }^{31}$ While he mentions that "many things are claimed by particular cultures, and that many things are privately owned", ${ }^{32}$ I wish to add that the normative content within the claim of a common heritage concept of all mankind might furthermore entail a provocation to the detriment of cultural heritage protection as this essentially includes a patriarchal Eurocentric or Western claim. ${ }^{33}$ While John Henry Merryman famously differentiated "Two Ways of Thinking about Cultural Property" 34 , namely a cosmopolitan and a national way, this contribution seeks to advocate for a grey zone: the regional perspective. ${ }^{35}$ Arguably, such a regional focus can more easily defuse parochial allegations, while still upholding a strong (institutional) protection.

"World heritage in the 1970s was seen as being defined by an essentially European, certainly Western, mindset" and indeed, "[a] global study carried out by ICOMOS [the International Council on Monuments and Sites] from 1987 to 1993 revealed that Europe, historic towns and religious monuments, Christianity, historical periods and 'elitist' architecture (in relation to vernacular) were all over-represented on the World Heritage List". ${ }^{36}$

30 Gillman, note 9, p. 15.

31 Gillman, note 9, p. 15.

32 Gillman, note 9, p. 15.

33 See in this regard - which is by no means meant as a justification - the chief of the Taliban Foreign Ministry press department Faiz Ahmed Faiz stating that the decision of destroying of the Bamiyan Buddhas "was not against anyone. It was totally a domestic matter of Afghanistan. We are very disappointed that the international community doesn't care about the suffering people but they are shouting about the stone statues of Buddha", again quoted after Gillman, note 9, p. 10 with further references to the New York Times, 26 March 2001 and other sources.

34 John Henry Merryman, Two Ways of Thinking About Cultural Property, American Journal of International Law 80 (1986), p. 831.

35 See, e.g., Francesco Francioni, The Human Dimension of International Cultural Heritage Law: An Introduction, European Journal of International Law 22 (1) (2011), p. 9 being certain that such a dichotomy "cannot adequately explain the present state of the law and, in particular, of international law. Today, there are more than just two ways of thinking about cultural property."

36 Ian Donnachie, World Heritage, in: Rodney Harrison (ed.), Understanding the Politics of Heritage, Manchester 2010, p. 115, 116 and 127. C.f. Marie-Theres Albert / Brigitta Ringbeck, 40 Years World Heritage Convention. Popularizing the Protection of Cultural and Natural Heritage, Berlin, Boston 2015, p. 5, identifying "an imbalance between Europe and Africa in terms of inscriptions 
Laurajane Smith, for instance, states that the 1972 World Heritage Convention "institutionalized the nineteenth-century conservation ethic". ${ }^{37}$ To her, this "inevitably universalizes Western values and systems of thought". ${ }^{38}$ Although a global strategy has led new countries to ratify the World Heritage Convention including now more formerly underrepresented regions and, thus, a greater diversity in heritage sites, this still is "not necessarily a significant move away from essentially elite culture dominated by the European mind set". ${ }^{39}$ Such a bias unfolds if we consider in addition the politics of cultural heritage protection. ${ }^{40}$

One example is the framing of heritage issues. "The language of the UNESCO conventions reinforces Western notions of values and rights, while the ownership and maintenance of the past is suffused with the concepts surrounding property". ${ }^{41}$ A more concrete example is the case of mummified heads of Māori warriors, which were set to be returned from France to New Zealand. The return, however, was blocked as the Administrative Tribunal of Rouen in France held that the return would violate French national heritage laws by removing them from France, as the Māori cultural identity would have meant to honour the

of cultural and natural heritage properties." They note that in Africa, the Arab States, Asia or Latin America especially in comparison to Europe, predominantly natural heritage is inscribed in the World Heritage List. In contrast, in Europe almost ten times as many cultural heritage sites are inscribed than in Africa (see, ibid, p. 6). As they reference (ibid, p. 6-7) an ICOMOS study displaying a dominance of "Christian monuments, Baroque castles and the royal residences of European sovereigns of the Renaissance", they state that this "goes beyond Eurocentrism". C.f. ibid, p. 2425 providing further statistics. In addition to that, many sites on the list located in Africa belong to the European colonial period. See Henry Cleere, The uneasy bedfellows: Universality and cultural heritage, in: Robert Layton / Peter G. Stone / Julian Thomas (eds.), Destruction and Conservation of Cultural Property, London 2001, p. 22, 26; see also for examples of the impact of racist colonizers on cultural heritage in Zimbabwe or Rhodesia, Helaine Silverman / D. Fairchild Ruggles, Cultural Heritage and Human Rights, in: Helaine Silverman / D. Fairchild Ruggles (eds.), Cultural Heritage and Human Rights, New York 2007, p. 3, 9-10; c.f. also Sophia Labadi, A review of the Global Strategy for a balanced, representative and credible World Heritage List 1994-2004, Conservation and Management of Archaeological Sites 7 (2005), p. 89. See also generally Kwame Anthony Appiah, In My Father's House. Africa in the Philosophy of Culture, London 1992; Robert Stam / Ella Shohat, De-Eurocentrizing cultural studies: some proposals, in: Ackbar Abbas / John Nguyet Erni (eds.), Internationalizing Cultural Studies: An Anthology, Oxford 2008, p. 481. Advancing the question whether an African-American historical archaeology can be an alternative voice: Mark P. Leone et al., Can an African-American historical Archaeology be an Alternative Voice?, in: Ian Hodder et al. (eds.), Interpreting Archaeology. Finding Meaning in the Past, London 2006, p. 110.

37 Laurajane Smith, Uses of Heritage, London, New York 2006, p. 27.

38 See Smith, note 37, p. 27 with further reference to Denis Byrne, Western hegemony in archaeological heritage management, History and Anthropology 5 (1991), p. 269.

39 Donnachie, note 36, p. 129.

40 See instructive Rodney Harrison, The politics of heritage, in: Rodney Harrison (ed.), Understanding the Politics of Heritage, Manchester 2010, p. 154.

41 See Lynn Meskell, Negative heritage and past mastering in archaeology, Anthropological Quarterly 75 (2002), p. 557, 568 (italics original). 
remains of a warrior by properly burying them in New Zealand. ${ }^{42}$ The conflict had been settled by the French Senate in 2009 in favor of Māori traditions, clearly stating that " $[\mathrm{t}] \mathrm{he}$ Māori heads that are still dispersed in European and US museums have a history that reminds us of the worst hours of colonialism". ${ }^{43}$ This can be seen to be in line with international heritage law as "no consideration for the general interest of humanity to have access and to preserve cultural heritage may in principle be considered as interfering with the right of the persons and/or communities specifically concerned to have the relevant human remains returned." 44 However and despite the distinction between objects on the one hand and human remains on the other hand, this example also enables one to take a deep look into how, even well-meant, cultural heritage protection and arguments for a common heritage of humankind, might disadvantage weaker voices. Another concrete example are the "ways in which highly innovative local Palestinian practices of heritage conservation tend to be silenced by the World Heritage mechanism" as this apparatus favors the nation state as a medium. ${ }^{45}$ In a similar vein, Lucas Lixinski claims that the major UNESCO treaties on cultural heritage protection have a negative effect. According to him, they prevented local communities not only from international decision making procedures, but actually from embracing their own heritage. ${ }^{46}$

However, a stronger regional cultural heritage protection could face criticism doubting the efficiency or the morale of such a regional focus. And particularly tensions in the MENA region have to be taken seriously. ${ }^{47}$ Against such doubts, that a regional protection would fall short of proper support for cultural heritage, speaks the support of representatives of Islamic countries such as Saudi Arabia, the United Arab Emirates, Qatar, Iran and Tajikistan or the president and the secretary of the Organization of the Islamic Conference.

42 See on this Federico Lenzerini, The Tension between Communities' Cultural Rights and Global Interests: The Case of the Maori Mokomokai, in: Silvia Borelli / Federico Lenzerini (eds.), Cultural Heritage, Cultural Rights, Cultural Diversity. New Developments in International Law, Leiden 2012, p. 157.

43 Quoted after Lenzerini, note 42, p. 159 who underlines this decision (ibid at p. 174) by finding "confirmation in the relevant international law applicable to the subject of the present enquiry".

44 Lenzerini, note 42, p. 177.

45 See on this Chiara De Cesari, World Heritage and mosaic universalism: A view from Palestine, Journal of Social Archaeology 10 (3) (2010), p. 299. C.f. also Irene Maffi, The emergence of cultural heritage in Jordan: The itinerary of a colonial invention, Journal of Social Archaeology 9 (1) (2009), p. 5, speaking of a "colonizer's affaire". Note, however, too, that UNESCO's General Conference has voted to include Palestine as a full member in 2011 and Palestine, thus, has ratified the World Heritage Convention in 2011 and has sites, such as the "Birthplace of Jesus: Church of the Nativity and the Pilgrimage Route, Bethlehem", included in the world heritage list.

46 See Lucas Lixinski, International Heritage Law for Communities: Exclusion and Re-Imagination, Oxford 2019, espec. p. 240 et seq highlighting "dark sides" of international heritage law.

47 Morag M. Kersel / Mounir Bouchenaki, Middle East and North Africa, in: Ana Filipa Vrdoljak / Francesco Francioni (eds.), The Oxford Handbook of International Cultural Heritage Law, Oxford 2020 , p. 931,937 pointing to "Israel's failure to ratify the 1970 UNESCO Convention" which - to them - complicates potential collaboration. 
All of them joined the call of the then UNESCO director-general, urging Mullah Mohammed Omar not to pursue the publicly declared goal of the Taliban to destroy Buddha statues in Afghanistan. ${ }^{48}$ That this call was initiated by the UNESCO points to the fact that the international arena must not withdraw from the pursuit of heritage protection in the MENA. However, the entire affair would profit, so runs the argument, if the regional protection were even stronger. ${ }^{49}$ This argument is supported by another declaration of the Taliban offering a non-religious motivation for demolishing the Buddha statues: a UNESCO delegation, investigating the prior destruction of objects in the Kabul Museum offering financial support for heritage preservation but declining financial support for other purposes such as providing nutrition for children. ${ }^{50}$

There are other voices, who suggest that at the international level the understanding of heritage should be reconsidered in the wake of the disastrous events mentioned in the introduction. For instance, Vivian Gornik advances the argument that UNESCO should "consider different approaches and philosophies to countering acts of war that destroy cultural heritage". ${ }^{51}$ She explicitly points to an understanding of heritage as a process (particularly emphasizing dynamic representations of the past which are also manipulated by power structures instead of a statist understanding of a somewhat objectified understanding), which has been put forward by Laurajane Smith. ${ }^{52}$ She even dares to suggest that such an understanding would allow "us to accept the possibility of [heritage destruction] in the face of war or acts of war" ${ }^{53}$ as pointed out by Cornelius Holtorf. ${ }^{54}$ Based on this understanding, Gornik proposes that "UNESCO, in addition to its current response protocols, [should] consider creating a new category for World Heritage destroyed by terrorism or as a result of human conflict." ${ }^{55}$ Thereby, the attempt to erase undesirable cultural heritage will be made unsuc-

48 See Harrison, note 40, p. 160-161.

49 See, e.g., Peter R. Schmidt, Community-Based Heritage in Africa. Unveiling Local Research and Development Initiatives, New York 2017, giving community-based heritage whose heritage is disappearing a voice.

50 See Harrison, note 40, p. 161-162 quoting a passage from Sayed Rahmatullah Hashimi in an interview with the New York Times saying that "The scholars told them that instead of spending money on statues, why didn't they help our children who are dying of malnutrition? They rejected that, saying, 'This money is only for statues'. The scholars were so angry. They said, 'If you are destroying our future with economic sanctions, you can't care about our heritage'. And so they decided that these statues must be destroyed [...] If we had wanted to destroy those statues, we could have done it three years ago. So why didn't we? In our religion, if anything is harmless, we just leave it. If money is going to statues while children are dying of malnutrition next door, then that makes it harmful, and we destroy it."

51 Vivian Gornik, Can UNESCO do More to Counter Terrorists' Destruction of World Heritage?, Present Pasts 6 (1) (2015), p. 1.

52 Smith, note 37.

53 Gornik, note 51, p. 2.

54 Cornelius Holtorf, Can less be more? Heritage in the age of Terrorism, Public Archaeology 5 (2006), p. 101.

55 Gornik, note 51, p. 2. 
cessful as the envisioned goal to make the world forget about this heritage is impeded. ${ }^{56}$ Here it is argued, that such an alternative "memory-list", would be in need of strong regional underpinning. In this vein, it is interesting to see, that also the success of the proposal of Blue Helmets for Culture, hinges upon the fact with whom such a body would interact with at the local and regional level. Local communities, whose property they are supposed to protect, are an essential part of such a proposal, too. ${ }^{57}$

Moving the region into the spotlight of cultural heritage protection, the MENA might arouse suspicion that religion, which played a central role in all three mentioned examples at the beginning, might hamper the envisioned goal of heritage protection. Such concerns, however, might be softened by a particular focus on regional international organizations as well as regional constitutions and their role in heritage protection. The relationship between Islamic law and constitutions is complex and involves many historical, political and sociological contextualizations which obviously cannot be provided here in passing by. ${ }^{58}$ Despite this caveat, Islamic heritage itself is worthy of protection as cultural heritage and thus asks for a neutral concept in order to avoid self-referential cycles. Beyond this argument a glance at regional initiatives and national legal orders shows that heritage protection is a concern in the region at which we will look more closely now.

\section{Focusing on Regional Cultural Heritage Protection in the MENA}

The Ottoman sultan Abdülhamid II at the end of the $19^{\text {th }}$ century envisioned a national archeological heritage policy. From this policy, however, he excluded the Arab provinces of the empire. ${ }^{59}$ Nevertheless, for instance, the timeline of the Antiquities Coalition, which is chronicling over a century of Arab legislation on cultural property protection, starts with the 1891 Decree on Excavations in Egypt, enshrining in Article 2 "All of the objects found

56 See for the discussion about the birth house of Adolf Hitler in Braunau am Inn, Austria, which was proposed to be blown up, Lando Kirchmair, Das „Geburtshaus Hitlers“ in Braunau am Inn - eine unendliche Geschichte?: Eine kritische Analyse der Legalenteignung auf Grund von Symbolik, Austrian Law Journal 5 (2018), p. 66.

57 See D'amico Soggetti, note 19, p. 165: "Participation of the local communities that developed/ cared for or are concerned about the heritage in question is crucial: without participation, no matter the experts' inputs, states can only implement a limited set of protection provisions for cultural heritage."

58 For an overview on Islamic Law and Constitutions, see Nathan J. Brown / Mara Revkin, Islamic Law and Constitutions, in: Anver M. Emon / Rumee Ahmed (eds.), The Oxford Handbook of Islamic Law, Oxford 2018, p. 779. C.f. for an examination of "Islamic constitutionalism" or something similar, Rainer Grote / Tilmann Röder, Constitutionalism in Islamic Countries: Between Upheaval and Continuity, New York 2011.

59 Maffi, note 45, p. 5, 7 with further reference to Daniel T. Potts, The Gulf Arab States and their Archaeology, in: Lynn Meskell (ed.), Archaeology under Fire. Nationalism, Politics and Heritage in the Eastern Mediterranean and Middle East, London 1998, p. 189; as well as Wendy M.K. Shawn, Possessors and Possessed. Museums, Archaeology, and the Visualization of History in the Late Ottoman Empire, Berkeley 2003. 
in excavations belong by right to the State and must be placed in the Giza Museum". ${ }^{60}$ And in fact, the 1869 "Turkish By-law on Antiquities (Asar-i Atika Nizam-namesi) provided the first formalized 'procedural and legal structure to regulate search, extraction, possession, and preservation of antiquities'. ${ }^{\prime 61}$ Elements of this law are still reflected in current legislation. ${ }^{62}$

After the First World War, "the new colonial states of the area started to elaborate a coherent policy aiming at creating institutions for the protection of cultural heritage." 63 Despite being a "colonizer's affair", this started excavations and archaeological museums yet, in a European fashion. ${ }^{64}$

In this vein, Webber Ndoro and Gamini Wijesuriya argue "that the systems and practice of heritage management experienced in parts of Asia and Africa today were imposed in these continents during the colonial period." 65 These "colonial heritage management systems appear to have also acquired a strong ally in the international and global institutions that seem to reinforce the heritage definitions, practice, and systems emanating from the colonial period." 66 This has consequences, so they argue, as local entities have little room to contribute and monumentality and physical remains are privileged in contrast to func-

60 All available at https://theantiquitiescoalition.org/understanding-the-problem/interactive-timelines/ (last accessed on 10 September 2020).

61 Kersel / Bouchenaki, note 47, p. 936 quoting Edhem Eldem, From Blissful Indifference to Anguished Concern: Ottoman Perceptions of Antiquities, 1799-1869, in: Zainab Bahrani / Zeynep Çelik / Edhem Eldem (eds.), Scramble for the Past. A Story of Archeology in the Ottoman Empire, 1753-1914, Cromer, Norfolk 2011, p. 281, 314.

62 Kersel / Bouchenaki, note 47, p. 936 with further references in note 27 as well as p. 957 pointing also to 1874 Ottoman legislation and again with further references in note 217.

63 Maffi, note 45, p. 5.

64 Maffi, note 45, p. 5. C.f. for the example of Iraq, Ana F. Vrdoljak, Unravelling the cradle of civilization 'layer by layer' Iraq, its peoples and cultural heritage, in: Michele Langfield / William Logan / Máiréad Nic Craith (eds.), Cultural Diversity, Heritage and Human Rights. Intersections in Theory and Practice, London 2010, p. 65. For a general overview, see Gilbert Pwiti / Webber Ndoro, The Archaeological Heritage of Africa, Cape Town 2014. C.f. on "[t]he dismemberment of the German colonial empire in Africa and the Pacific and the Ottoman Empire in the Middle East and North Africa [which] did not lead to the independence of these territories. Accordingly, the Allied Powers dominated the new political and territorial order and considered the formerly colonized peoples as backward, unable of withstanding the challenges of the modern world." Andrzej Jakubowski, State Succession in Cultural Property, Oxford 2015, p. 83 et seq.

65 Webber Ndoro / Gamini Wijesuriya, Heritage Management and Conservation: From Colonization to Globalization, in: Lynn Meskel (ed.), Global Heritage. A Reader, Hoboken New Jersey 2015, p. 131. C.f. ibid p. 134 et seq where they also do away with "[o]ne of the most commonly held misconceptions [which] is that there was no system of heritage management and conservation in precolonial Africa and parts of Asia" and point to further references in this regard: Thierry Joffroy, Traditional Conservation Practices in Africa, Rome 2005; and Gamini Wijesuriya, Are We Reinventing the Wheel? Archaeological Heritage Management under the British Colonial Rule in Sri Lanka, in: Susan Lawrence (ed.), Archaeologies of the British: Explorations of Identity in the United Kingdom and Its Colonies 1600-1945, London 2003, p. 274 in this regard.

66 Ndoro / Wijesuriya, note 65, p. 131. 
tionality, meaning and community connections. ${ }^{67}$ In addition, this is not an issue of the past, as in the post-colonial areas "[i]n Africa and Asia, even after fifty years of independence the majority of heritage legislation continues to reflect the management systems introduced during the settler colonial era." 68 While their argument broadly spans Africa and Asia, it is equally relevant for the MENA. Generally speaking, it is hard to strictly differentiate between the MENA and Africa as the "classification" of countries to both regions overlap. While this article advocates for a regional focus, this does not mean, that a single institution shall or can be competent to deal with cultural heritage protection. Similarly as this article does not argue for a full withdrawal of international institutions in the MENA region, neither an exclusive focus is to be preferred. In this vein, policies and regional agreements as well from the Arab League and the African Union can in fact contribute to the strengthening of a more regionally oriented focus of cultural heritage protection.

Having said that, for our purpose in this article, it is of particular interest what Ndoro and Wijesuriya identify as an upfront challenge. Namely, "[t]he challenge for local heritage practitioners and experts is how to include non-European views within the concept and processes of World Heritage." ${ }^{69}$ Definition and standards of management are particularly affected by a Western bias, which in turn, makes local heritage management more difficult. ${ }^{70}$ It is argued here that the regional level and regional organizations could play an important mediator to address the challenge faced and mitigate the burden stemming from a Eurocentric and / or Western bias in cultural heritage protection. ${ }^{71}$ A regional and local focus, how-

67 Ndoro / Wijesuriya, note 65, p. 131 with further reference to Emma Waterton, Politics, Policy and the Discourses of Heritage in Britain, London 2010; as well as Shadreck Chirikure / Gilbert Pwiti, Community involvement in archaeology and cultural heritage management: An assessment from case studies in Southern Africa and elsewhere, Current Anthropology 49 (3) (2008), p. 467.

68 Ndoro / Wijesuriya, note 65, p. 139.

69 Ndoro / Wijesuriya, note 65, p. 145.

70 Ndoro / Wijesuriya, note 65, p. 145.

71 For a general overview, see Fekri Hassan / Aloisia de Trafford / Mohsen Youssef, Cultural Heritage and Development in the Arab World, Alexandrina 2008; for an overview of legal instruments on heritage protection in Arab countries, see Kersel / Bouchenaki, note 47, p. 938 et seq; as well as the background paper by Ridha Fraoua, Legislative and institutional measures to combat trafficking in cultural property in Arab States, for participants in the Second Meeting of States Parties to the 1970 Convention UNESCO Headquarters, Paris, 20 and 21 June 2012, available at http://www. unesco.org/new/fileadmin/MULTIMEDIA/HQ/CLT/pdf/Fraoua_en.pdf (last accessed on 10 September 2020); c.f. Christine Irsheid, The Protection of Cultural Property in the Arab World, International Journal of Cultural Property 6 (1) (1997), p. 11; for an overview in English-speaking sub-Saharan Africa, see Webber Ndoro / Albert Mumma / George Abungu (eds.), Cultural Heritage and the Law. Protecting immovable heritage in English-speaking countries of Sub-saharan Africa, Rome 2008; Noemie Arazi / Ibrahima Thiaw, Managing Africa's Archaeological Heritage, in: Peter Mitchell / Paul J. Lane (eds.), The Oxford Handbook of African Archaeology, Oxford 2013, p. 213; Webber Ndoro / Shadreck Chirikure / Jeanette Deacon (eds.), Managing heritage in Africa. Who cares?, London 2017; for an overview of applicable national cultural heritage laws, see the UNESCO database, available at https://en.unesco.org/news/unesco-database-national-cultural-herit age-laws-updated/ (last accessed on 10 September 2020). 
ever, is not free from risks and difficulties which are inherent in such a perspective. The Turkish Cooperation and Coordination Agency (TIKA), established in 1992, which is focused on Islamic heritage, for instance, specifically supports the restoration of mosques in the Balkans, the Middle East, and Africa in a way that aims at continuing the Ottoman enterprise. In so doing, this agency "does attempt to hide its political, religious, and/or cultural motivations in its support of heritage and the fostering of Turkish ideals." 72 Its model, however, "is aggressive and highly strategic". ${ }^{73}$

In a way as a contrast point to those challenges, the most recent entry in the Antiquities Coalition timeline is the Arab League's Parliament "Guiding Law for the Preservation and Protection of Arab Antiquities" from 4 February 2020. This law serves as a sort of blueprint for Arab States when updating their national legislation. ${ }^{74}$ Generally speaking, the Arab League Educational, Cultural and Scientific Organization (ALECSO) provides for a regional focus on cultural heritage protection in Arab states founded in 1970 within the realm of Article 3 of the Arab Cultural Unity Charter adopted in 1964. And indeed, the Regional Centre of the International Centre for the Study of the Preservation and Restoration of Cultural Property in Sharjah organised the Arab Cultural Heritage Forum, precisely "to develop philosophical principles and approaches, based on local and/ or regional perceptions, aimed at promoting and preserving heritage places and artworks in the Arab world." 75

In contrast to the Council of Europe's approach, which is said to be focused on "built heritage and cultural landscapes", the African Union is more concerned with "heritage as a common living culture of African Peoples". ${ }^{76}$ This is related to "[a]n important wider context within which policies and laws are developed for the protection of cultural heritage". ${ }^{77}$ In addition to this institutionally organized protection, also international agreements are of importance. Human rights in general, and in Africa particularly the African Charter on Human and Peoples' Rights from 1981, known as the 'Banjul Charter', adopted on 27 June 1981, are of importance in this context. ${ }^{78}$ Especially Article 22 (1) of the Banjul Charter stipulates that "[a]11 peoples shall have the right to their economic, social and cultural development with due regard to their freedom and identity and in the equal enjoyment of the

72 Morag M. Kersel / Christina Luke, Civil Societies? Heritage Diplomacy and Neo-Imperialism, in: Lynn Meskel (ed.), Global Heritage. A Reader, Hoboken New Jersey 2015, p. 70, 84. See also Christina Luke, Cultural sovereignty in the Balkans and Turkey: The politics of preservation and rehabilitation, Journal of Social Archaeology 13 (3) (2013), p. 350.

73 Kersel / Luke, note 72, p. 85.

74 All available at https://theantiquitiescoalition.org/understanding-the-problem/interactive-timelines/ (last accessed on 10 September 2020).

75 Arab Cultural Heritage Forum, A Think- Tank Meeting informing a Vision for the Conservation and Promotion of Cultural Heritage in the Arab World (2018), available at https://www.iccrom.org /arab-cultural-heritage-forum (last accessed on 10 September 2020).

76 Lucas Lixinski, Intangible Cultural Heritage in International Law, Oxford 2013, p. 67.

77 Janet Blake, International Cultural Heritage Law, Oxford 2015, p. 315.

78 All African countries typically included in the MENA (except Morocco) have ratified this Charter. Algeria (1987), Egypt (1986), Libya (1987) and Tunisia (Adherence 1986). 
common heritage of mankind." In the Arab world, Article 2 (1) of the Arab Charter on Human Rights similarly holds that "[a]ll peoples have the right of self-determination and to control over their natural wealth and resources, and the right to freely choose their political system and to freely pursue their economic, social and cultural development."79 Article 25 of the Arab Charter on Human Rights additionally states that "[p]ersons belonging to minorities shall not be denied the right to enjoy their own culture, to use their own language and to practice their own religion. The exercise of these rights shall be governed by law."

Furthermore, the 2017 revised African Convention on the Conservation of Nature and Natural Resources, adopted by the African Union at Maputo, Mozambique on 11 November $2003,{ }^{80}$ is in force and has at least indirect influence on the MENA as this convention has been ratified by Libya. However, other countries typically attributed to the MENA region, which could also ratify the agreement as members of the African Union such as Egypt, Morocco or Tunisia have not ratified the convention yet. Changing this could be of importance for a regional account advocated in this article as precisely this convention has been described as "the most modern and comprehensive of all agreements concerning natural resources". ${ }^{81}$ The Preamble, for instance, stipulates that the conservation of the global environment is a common concern of humankind. Furthermore, especially the conservation of the African environment is a primary concern of all Africans according to this convention which in turn, could influence also the MENA. Another important convention is the Charter for African Cultural Renaissance, which still has not entered into force as two thirds of all Member States of the African Union must have ratified the convention in order for it to enter into force. ${ }^{82}$

Also of importance for cultural heritage protection in Africa, and thus in North Africa too, is the Agenda 2063 adopted in January 2013 at the African Union Summit, entitled "The Africa We Want". ${ }^{83}$ The Pan African perspective of the agenda, envisioning Africa in 2063, aims at "an integrated, prosperous and peaceful Africa, driven by its own citizens and representing a dynamic force in the global arena" ${ }^{84}$ The goal is clear: "Despite all the threats to Africa's cultural heritage, the values of African people remain on a solid foundation both on the continent and in the diaspora. African renaissance and self-confidence is

79 League of Arab States, Arab Charter on Human Rights, May 22, 2004, reprinted in 12 Int'l Hum. Rts. Rep. 893 (2005), entered into force March 15, 2008. C.f. for a critical discussion, Mervat Rishmawi, The Revised Arab Charter on Human Rights: A Step Forward?, Human Rights Law Review 5 (2) (2005), p. 361.

80 Available at https://au.int/sites/default/files/treaties/7782-treaty-0029_-_revised_african_conventio n_on_the_conservation_of_nature_and_natural_resources_e.pdf (last accessed on 10 September $2020)$.

81 Alexandre Kiss / Dinah Shelton, Guide to International Environmental Law, The Hague 2007, p. 184.

82 With currently 14 ratifications available at https://au.int/sites/default/files/treaties/37305-treaty-00 32_-_charter_for_african_cultural_renaissance_e.pdf (last accessed on 10 September 2020).

83 Available at https://au.int/en/agenda2063/overview (last accessed on 10 September 2020).

84 Ibid. See also Blake, note 77, p. 318. 
critical to the continent's progress." 85 Within the realm of this agenda, for instance a "Great Museum of Africa" is planned to be launched in 2023. ${ }^{86}$ "The Museum of Africa Permanent Memorial of Slave Trade will showcase, protect and promote the rich cultural heritage of the continent, and will be hosted by the People's Democratic Republic of Algeria in Algiers." 87 This is part of an important aspiration of the Agenda, envisioning "strong cultural identity values and ethic". ${ }^{88}$ Janet Blake rightly highlights the Agenda's "goal that "Pan Africanism and the common history, destiny, identity, heritage, respect for religious diversity and consciousness of African people's and her diaspora's will be entrenched' and that Africa's 'diversity in culture, heritage, languages and religion shall be a cause of strength'. In addition, '[c]ulture, heritage and a common identity and destiny will be the centre of all our strategies so as to facilitate for a Pan African approach and the African Renaissance'" 89

The more recent Charter of the Organization of the Islamic Conference, a revised Charter adopted at the Eleventh Islamic Summit held in Dakar on 13-14 March 2008, is also worth mentioning, as the Preamble sets out to promote unity and solidarity among its Member States, thereby including also the fostering of "Islamic symbols and common heritage" ${ }^{90}$ In addition, the Arab Regional Centre for World Heritage (ARC-WH) was founded in 2012 as a so-called Category II Centre under the auspices of the UNESCO. Although linked to UNESCO, it is an autonomous and independent legal entity located in Bahrain which seeks to preserve and protect cultural and natural heritage sites in Arab countries by supporting and strengthening the implementation of the 1972 World Heritage Convention. ${ }^{91}$

Furthermore, there are several national organizations such as the Association for the Protection of Syrian Archeology that protect vulnerable heritage sites for instance, by collecting evidence of crimes against heritage. ${ }^{92}$

Beyond such institutionalized heritage protection in the region, it is also very encouraging, and arguably speaks also to the argument advanced in this article, that civil society actors showed much enthusiasm and took great risks in order to protect heritage. Helena Turku points in this regard to the example of protesters facing looters who attacked the Egyptian National Museum in Cairo in 2011. She explains that antigovernment protesters formed a human chain to protect the museum when Egyptian soldiers tried to fend off looters. She quotes Zahi Hawass, Egypt's chief archeologist, who said that: "They know this is

85 See the Agenda 2063 Framework Document, p. 70.

86 See The First Continental Report on the Implementation of Agenda 2063 (February 2020), p. 2, available at https://www.nepad.org/publication/first-continental-report-implementation-agenda-20 63 (last accessed on 10 September 2020).

87 Ibid.

88 E.g., Agenda 2063 Framework Document, p. 93.

89 Blake, note 77, p. 318 with further references.

90 See Blake, note 77, p. 332.

91 For its latest 2019 annual report, see http://arcwh.org/filePdfs/ARC-WH-2019-Annual-Report-Eng .pdf (last accessed on 10 September 2020).

92 Turku, note 13, p. 175. 
their cultural heritage... If the museum is safe, Egypt is safe." Likewise, the Library of Alexandria received protection by protesters "by joining hands around the building". 93

\section{E. Conclusion and Outlook}

International cultural heritage protection is not meaningless in the MENA. For instance, UNESCO's intervention and support for cultural heritage in face of the construction of the Aswan Dam on the Nile River in the 1960s in Egypt is a good example of how international institutions can and should play an important role in heritage protection. ${ }^{94}$ Also, UNESCO's more recent attempt to "empowering youth to build peace through the protection and preservation of heritage" in realm of the Arab World Heritage Young Professionals Forum certainly might qualify as an effective tool which includes regional needs meaningfully. ${ }^{95}$ And the conviction of Al Mahdi by the ICC too conveyed an important message: Grave violations of international cultural heritage laws in the form of war crimes do not go unpunished.

And yet, Ndoro and Wijesuriya precisely identify in the campaign to save the Abu Simbel temple and other ancient monuments in the Nile Valley the "beginning of an uneasy relationship between heritage protection and what was considered to be the needs of development in the two [Africa and Asia are the examples referred to by the authors] regions". ${ }^{96}$ Despite such a helpful support, it is nevertheless important, that the identity-constructing function of cultural heritage is better respected, when the primary support and protection of heritage comes from the region itself.

Obviously, the author of these lines is not the appropriate voice for detailing the suggested stronger focus on the regional level in the MENA. Yet, it might be a small contribution to move the spotlight, which still is directed by a Eurocentric or Western standpoint, from an international focus to a stronger regional approach. For instance, initiating or supporting an interdisciplinary comparative analysis of cultural heritage protection in the region discussed in this article - not as a top down exercise, but more as a grassroots scholarly endeavor - could be a meaningful continuation of shifting the focus from an international

93 See Turku, note 13, p. 175.

94 See Kersel / Bouchenaki, note 47, p. 958 concluding that UNESCO might act as a coordinator in preventing illicit trafficking and destruction of cultural heritage, might strengthen a network between international and national actors. According to them, UNESCO, in this vein, might even "harness the power of heritage as a positive and unifying force" which, in turn, "can help prevent conflicts and facilitate peace-building, recovery, and reconciliation".

95 See, e.g., the recent call available at https://whc.unesco.org/en/news/2021/ (last accessed on 10 September 2020). Also the Arab German Young Academy's working group on common heritage and common challenges fosters academic exchange between young Arab and German academics with an interdisciplinary focus on cultural heritage. For more information, see http://agya.info/wor king-groups/common-heritage-and-common-challenges/ (last accessed on 10 September 2020).

96 Ndoro / Wijesuriya, note 65, p. 133. 
towards a more regional cultural heritage protection in the MENA. ${ }^{97}$ While this is not the right place to directly address how the regional MENA regime could and should be different in comparison to the international legal system of cultural heritage protection, such a regional focus arguably would strengthen the necessary ties between cultural heritage and its identity constituting function for communities. To strengthen such a regionally and locally situated enterprise a comparative exercise might be supportive in order to answer questions as to what specificities (in terms of substantive and procedural rules) are necessary for such a regional approach in order to do justice to the identity constituting function of cultural heritage in the region. What kind of an institutional framework is suitable for such a regional regime in order to handle political and religious specificities is another set of topics which could be addressed in such an exercise. ${ }^{98}$ The same holds true for compliance mechanisms which might differ in order to fulfill their purpose. These and many more questions are pondering, indeed. However, the argument advanced in this article forbids answering them in the same breath as asking them. These questions must largely remain to be answered from a local and regional perspective. This way, also regional voices and perspectives could be amplified. Also, this might strengthen regional voices on the international level and thereby further diversity and cooperation.

97 For the fundamental role of culture "through which all aspects of law must be perceived", however not "merely in terms of indicators that can be proposed (controversially) at a relatively abstract level, but also as far as possible in terms of its intimate meaning for those who participate in it", see Roger Cotterrell, Comparative Law and Legal Culture, in: Mathias Reimann and Reinhard Zimmermann (eds.), The Oxford Handbook of Comparative Law, Oxford $2^{\text {nd }}$ ed 2019, p. 710, 711 and 732. On the methodological underpinning of comparative law generally, see Uwe Kischel, Comparative Law, Oxford 2019, p. 152 et seq, who calls for a "contextual approach" as the appropriate method of comparative law. In so doing, however, it is important to especially keep the potential pitfalls (or in Kischel's wording [ibid p. 31 et seq] the necessary "modesty") of such an exercise in mind. See only the critique by Günter Frankenberg of Uwe Kischel's, Rechtsvergleichung, München 2015, "Rechtsvergleichung" - A New Gold Standard?, Zeitschrift für ausländisches öffentliches Recht und Völkerrecht 76 (2016), p. 1001. While it is important to keep the context in mind, it seems also necessary - for the enterprise suggested here - to leave the analysis and especially the "right" or rather concrete answers as to how to design a stronger regional protection of cultural heritage to the respective regions.

98 See generally on fundamental differences in comparative public law between a Western perspective, focusing on nation-states and territory on the one hand ("territorial model"), and Islamic law, being dominated by a personal dimension on the basis of religion on the other hand ("personal model"), Chibli Mallat, Comparative Law and the Islamic (Middle Eastern) Legal Culture, in: Mathias Reimann and Reinhard Zimmermann (eds.), The Oxford Handbook of Comparative Law, Oxford $2^{\text {nd }}$ ed 2019 , p. 624, 638 et seq, as well as 650-651. C.f. on the importance of customary law in Africa, T. W. Bennett, Comparative Law and African Customary Law, in: Mathias Reimann and Reinhard Zimmermann (eds.), The Oxford Handbook of Comparative Law, Oxford $2^{\text {nd }}$ ed 2019 , p. 653,653 precisely starting with a "warning": "Since the start of the European colonization of Africa, and even in its aftermath, perceptions of the continent's indigenous systems of customary law have been decidedly Eurocentric, a bias that has until recently also marked comparative law. Hence, when we come to explore the position of African customary law in comparative legal studies, it is immediately evident that European laws provide the standards for comparison." 